\title{
THE EXPERIENCE OF ECONOMICAL MODERNIZATION OF MUNICIPAL ECONOMY IN THE SOUTH OF UKRAINE IN THE SECOND HALF OF XIX - AT THE BEGINNING OF XX
}

\section{Cheremisin O. V.}

\section{INTRODUCTION}

The article is dedicated to the research in history of municipal self-government in the south of Ukraine in the end of XVIII - at the beginning of XX c. The budgeting policy is analyzed as well as the municipal economy, the participation in social-economical life of local population and its role in engineering-technical provisions of local communities' interests. The major attention is paid to the experience of local municipal self-government in modernization of economical potential on a regional scale in southern Ukraine ${ }^{1}$.

The southern region was special in a lot of peculiarities which differentiated it substantially from others. For a long time the empire tried to realize the "Novorusia project", but the policy failed. The region was populated by the Ukrainians forming itself in close economical and socialcultural relationships with the right and the left bank Ukraine and it eventually became an integral part of Great Ukraine. The spirit of free enterprising was spread widely here; there were no serfdom practically and through the southern ports not only goods but ideas of modernized Europe were also imported, in particular concerning specifics of municipal and administrative management. In comparison with other regions of Ukraine modernization and urbanization took place very fast here. Towns had large land resources, developed economy and substantial trade and industrial connections ${ }^{1}$.

The majority of researchers in history of municipal self-government put an emphasis on an exceptionally positive role of municipalities in the studied period, especially in the second half of the XIX - at the beginning of XX c., as public institutions of power did their best in: development of enterprising; ports' modernization, building of railways, increase in expenses on medicine and education, making substantial progress in cultural institutions and other achievements.

${ }^{1}$ Turchenko F.H., Turchenko H.F. (2003). Pivdenna Ukraina: modernizatsiia, svitova viina, revoliutsiia (kinets XIX st. - 1921 r.): Istorychni narysy. [South Ukraine: Modernization, World War, Revolution (end of the XIX century - 1921): Historical essays.]. K. : Heneza. 304 s. [in Ukrainian] 
During the modernization's period of the second half of the XIX-XX c. a role of municipal self-government manifested it self in:

- the development of industry; municipal self-government was taken out of the system of factory legislation, which put an obstacle to the development of public society. Municipalities, in their turn, were completely satisfied with receiving particular revenues to the budget being interested in nothing more. Even enterprises which after the Reform in the middle of the XIX c. had been municipalized were quickly leased and the management was not interested in the working conditions of people in these enterprises, it was completely satisfied that the Government took over security functions. Revolutionaries used this situation in their ideology of transition from capitalism to socialism. In general, in 1870-1917 in regard to industrial development municipal self-government made a substantial step forward in comparison with the before Reform period, when municipal administration was not interested in this branch of economy at all, but the above step forward was not sufficient enough, because municipal administration's role was limited to leasing land for building industrial enterprises;

- the participation in building a network of railroads and ports' modernization in which municipalities showed more mobility. Although ideas and initiatives concerning the organization and building of railway were produced inside the Governmental apparatus which played a strategic role in connecting central regions with ports the financial burden was still put upon foreign and private companies. Municipal self-government by taking part in this process concentrated ideas and led organizers of the above construction of the railways to building these through their own towns. Municipalities also built their own railways from stations to ports and to industrial enterprises doing their minimum. As their maximum - municipalities built railroads on a subregional level, which connected the left and right bank Ukraine.

- the modernization of land property, which referred to the minority of towns in southern Ukraine, satisfied everyone with leasing lands without a problem of increase in productivity and thus they took off an enterpriser's responsibility, having minimal guaranteed income from the leaseholder instead.

In general, notwithstanding the fact that the modernization of southern Ukrainian towns was rather fast, it was still unfinished. However, in comparison with other regions of the empire the situation in the south of Ukraine was much better. Budgets were growing with bigger rate as well as urbanization was taking place quicker and much more expenditure was directed to educational-cultural and medico-sanitary measures; towns' development took place faster. Municipalities conducted modernization of engineering-technical infrastructure independently and did not share experience with their neighbors. Still without financial support of the State, banking establishments as well as the participation of local enterprisers municipalities would not be able to conduct innovations. 


\section{Modernization of municipal land fund \\ by local self-governmental bodies}

The municipal regulation from 1870 made certain changes in development of municipal land policy. The changes were connected mainly with purchaseselling process of land property. Thus, the new regulation granted rights to municipal self-government bodies on behalf of the public to purchase and alienate real estate, to make contracts, to act as a plaintiff in a court and to take part in property quarrels as a defendant. With compliance with it municipalities had the right to land resources, the right to define prices for renting or to use municipal land resources, to grant concessions to build various enterprises on municipal lands which were incorporated into towns or were out of their boundaries.

It was defined that municipal lands were objects of market relationships. The control over the doings of municipal self-government bodies in the sphere of land policy was strengthened after the Municipal Reform from 1892. For example, according to the new regulation municipalities were obliged to fix prices on land resources after it was agreed with Gubernators and the Minister of Home affairs was obliged to approve of decisions of municipal self-government concerning the alienation of immobility. Thus, the control over conducting municipal land policy was shared between different levels of competence, which sufficiently made situation less adapted to market conditions.

In all towns' budgets of the southern Ukrainian region a particular item was specified which towns received due to using municipal land resources.

In comparison with the previous period due to this item there increased revenues to budgets. For example, the largest revenues could be only Kherson's pride $(43,4 \%)$, so this item of the budget was regarded as priority for the city. In Mariupolrevenues from using municipal land property were $23,8 \%$, in Elisavetgrad - 40\%, in Katherinoslav - 20\%, Oleksandrivsk made $20 \%$, in Yalta revenues to the budget during the studied period fluctuated from $47 \%$ in 1870 , in $1872-15 \%$, in $1887-65 \%$ to $13 \%$ in 1894 and at the beginning of the XX century it was 15\%, in Simferopol - 23\%, in Eupatorium $-30 \%$, in Kerch-Enikaleadministrative area - 30\%, in Ackermann $30 \%$, in Odessa $-12 \%$, in Mykolajiv - 20\%, in Sebastopol - 20\% ${ }^{3}$. In all other towns revenue to budgets from land municipal property made approximately the same varying from $20 \%$ to $30 \%{ }^{2}$.

${ }^{2}$ Cheremisin A. (2014). Municipal budgets of the southern Ukraine at 1785-1870. British journal of science, education and culture. 1 (5). P. 17-24. [in English].; Cheremisin O. V. Miski biudzhety Pivdnia Ukrainy v 1870-1917 rr. Naukovi zapysky Ternopilskoho natsionalnoho universytetu im. V. Hnatiuka. Seriia: Istoriia. Ternopil : Vyd-vo TNPU im. V. Hnatiuka, 2015. Vyp. 1. Ch. 2. S. 17-23. [in Ukrainian]. 
This was regional-individual specifics of towns in the southern Ukraine, as in other regions revenue from municipal land property was too minimal or even absent.

Not a kopek from the above mentioned revenue was spent on the development of municipal land resources. The land policy of self-government bodies was realized in the way by which all the burdens of expenditure connected with land usage were put upon pockets of leaseholders. The money from leasing land was redirected to unprofitable items: supporting educational institutions, medical service, returning debts and credits.

The least sum of revenues to the budget was in Odessa, as the whole land was shared into allotments of 12 des. which were available for leasing; it was prohibited to sublease land there, which made it impossible to concentrate land in one's hands, instead it made land available for leaseholders ${ }^{3}$.

L. Tsybulenko thinks very reasonably that Kherson's self-government dealt seriously with problems of development of land property and worked constantly on improving its productivity. In order to rationally organize the land resources the municipality shared municipal arable land into 5 categories depending on its cost. It led to a minimal level of speculations connected with land economy. Demographic growth of population was accompanied with diminishing of leaseholders' farmland. Kherson's self-government bodies tried to adopt the experience of GB, German and USA, so it systematically took care of fermenting soils, development of nitric-absorbing bacteria, mixed fruit rotation and usage of sophisticated mechanisms. At the edge of the XIX - XX c. the municipality thought that it was not enough to just gain rent for exploiting municipal land property, so it thought it was necessary to work out fix-term programs of optimal land usage which lay in irrigation, fields processing and sensible crop rotation ${ }^{5}$.

Odessa's municipality worked out a creative and rational way of exploiting land resources with the aim of increasing profitable revenues to the budget, finding alternative variants of developing farming and meeting demands of town's population for land.

However, in spite of considerable efforts of Odessa's self-government bodies after 1912, we can notice an abrupt decrease in corresponding revenues to the budget, which was connected with bad harvests. That is why it was necessary to make substantial efforts to prevent leaseholders of municipal lands from bankruptcy. The problem was connected with low provision of

${ }^{3}$ Tsybulenko L.O. (2001). Diialnist orhaniv samovriaduvannia Odesy, Mykolaieva, Khersona shchodo formuvannia i rozvytku munitsypalnoi zemelnoi i vyrobnychoi vlasnosti v XIX - na pochatku XX stolit. [Activities of self-government bodies of Odessa, Nikolaev, Kherson on the formation and development of municipal land and industrial property in the XIX - early XX centuries]. Dnipropetrovsk. S. 32-40. [in Ukrainian]. 
town's leaseholders with technical facilities for land processing, which influenced a decrease in productivity of labor and an increase in rent. Judging from the above-mentioned we come to a conclusion about a low level of agriculture on municipal lands. In conditions of growing demands for lands the municipality organized public auctions at high prices. It was planned that this measure would increase revenues to the budget, although in 1914 the city managed to gain only 73 thousand rubles which was only $1.6 \% 4$.

In the studied period it was a common practice concerning development of municipal land property to lease land by public auction. Municipality of Mykolajivrefused from this practice. In Mykolajiv the term of land lease was shortened to 1 year. In 1903 the Department brought up a question of raising productivity of labor on municipal lands. Partially this problem was to be solved by means of irrigation. For this purpose, while making contracts on land lease, leaseholders were obliged to improve a system of irrigation wheels. The similar measures led to increasing in land cost notwithstanding the fact that 4 thousands des. were allotted to municipal land property in 1896. In general, revenues to the budget from agricultural sector were rather big and in spite of constant shortages they constituted a substantial part of the budget and were 223203 rubles in 1913, that is $20.1 \%^{6}$.

Pastures constituted a certain part in the agriculture's structure of all towns in the southern Ukrainian region. According to the Municipal regulation from 1870 all active pastures were allotted to municipal land property on general conditions and all revenues from their exploiting were allotted to municipal budgets. Under the above conditions municipalities charged fees for feeding cattle and formulated rules and methods of taxation. There were cases when self-government bodies refused townspeople to feed their cattle on municipal lands; in some towns self-government bodies provided opportunities for free feeding of cattle. In general, it was a common practice for municipalities and municipal communes to make special contracts on cattle feeding. The variety of practice maybe explained by the fact that before the Reform period fields for cattle feeding were not taxed on at all, as these were legally attached to rural communities and were regarded as property of the State. After 1871 land for pastures was allotted to municipal self-government bodies that were able to manage lands themselves acting in accordance with the interpretations of appeal department of the Senate.

${ }^{4}$ Tsybulenko L.O. (2001). Diialnist orhaniv samovriaduvannia Odesy, Mykolaieva, Khersona shchodo formuvannia i rozvytku munitsypalnoi zemelnoi i vyrobnychoi vlasnosti v XIX - na pochatku XX stolit. [Activities of self-government bodies of Odessa, Nikolaev, Kherson on the formation and development of municipal land and industrial property in the XIX - early XX centuries]. Dnipropetrovsk. S. 32-40. [in Ukrainian]. 
As a result, L. Tsybulenko ${ }^{7}$ in her research makes conclusions that municipal property had certain legislative limits, though it continued its development. Mechanisms of aren't scheme of different land categories were formed, a system of stimulating was worked out in regard to the usage of achievements in agro-engineering and, in case it was necessary, a system of favorable conditions for farmers was applied. An increase in price for rent led to an increase in revenues to the budget. Economical activity was remarkable not only for persistence, but also for a creative attitude to using scientific potential as well as achievements of Novorossiysk University.

As a result, it appeared that a few towns conducted modernizational measures in developing agriculture trying to sufficiently improve and modernize land tenure on municipal lands and to eventually increase the profitability of budgets. In other towns of the province municipalities were absolutely satisfied with collecting rent and thus limiting themselves in activity. In provincial towns there were even no traces of modernizing land policy, as these were mentally still in the before Reform period. The changes in the legislation as well as the modernizational examples in regional centers did not influence the work of self-governmental institutions in small towns and those in the majority of subregional centers.

We can agree to V. Konstantinova's $\mathrm{s}^{5}$ thought that in land policy of municipal self-government bodies collecting of rent took the priority and municipalities worked out various schemes of such services according to different categories of land. At the same time, in different towns this problem was solved on an individual basis by finding a compromise between the interests of municipality to fill a budget or to defend the interests of municipal population and small leaseholders. We should also agree that municipal selfgovernment bodies did differently in regard to an individual basis as well as in regard to a regional scale, as municipal self-governmental institutions in Kherson's province were busier with leasing land for farming agriculture products (wheat, barley, winter crops and others)than with cattle breeding on municipal lands, whereas municipalities of Katherinoslav province made efforts in granting land on lease aiming at industrial construction and creating on its basis a system of capital buildings; municipal self-government bodies in Tavrijska province were traditionally busy with development and protection of gourds in the limits of municipal land fund.

The problem of unauthorized seizure of municipal land property was crucial for every self-government body and a town solved it on an individual

${ }^{5}$ Konstantinova V. M. (2010). Urbanizaciya: pivdennoukraïnskij vimir (1861-1904 rokah). [Urbanization: South-Ukraini and imension (1861-1904)]. Zaporizhzhya : AA Tandem. S. 216-217. [in Ukrainian]. 
basis: from beating a owner of land, an arbitrary choice of land and ruination of buildings - to bringing unauthorized farmers to a court ${ }^{6}$. For example, in Eupatorium it was a usual practice, especially during a resort season, to seize a tavern or to build it for holiday-makers without permission. Local police being informed by the municipality found such places and moved out their quests. The eviction was rather rude, with beating and putting into jail. The author can partially agree to V. Konstantinova's opinion that the most characteristic situation took place in Katherinoslav where the poor were simply satisfied with seizure of forlorn lands, whereas richer people did openly, widely and for their future benefits. The examples of this sort can be found in every town.

According to the author's opinion the situation with the misuse on municipal lands was deeper and more complicated, because such doings caused abuses, speculations and conflicts. The whole complex of the above problem can be divided into several (5)categories.

The first category - interethnic misuses with unauthorized seizures of land. For example, in 1830 a well-known conflict between Armenian and Slavish population took place about municipal land in Grygoropol quoting as an authority to Paul's Deed from 1798. The Government trying to solve the conflict made certain concessions and established a municipal selfgovernment institution in this town with the aim of settling quarrels.

In 1870 s the Greeks from Mariupol ${ }^{10}$ decided that municipal lands belonged to them quoting as an authority to the Deed from 1779, but Municipal Duma made a decision that municipal land belonged to the city not to separate nationalities.

The second category - economical misuses when municipal lands were grabbed arbitrarily with the aim of selling and reselling them to private hands and thus they were artificially removed from civilized turnover. This problem would appear both before the Reform period and after.

The third category - communal misuses connected with the doings of municipal self-government bodies, as they by their own decisions were able to replace land tax with valuation one, which was in contradiction with active legislation or with the help of police to grab crops from small leaseholders (at the same time to change the terms of rent), which was more characteristic of towns in Kherson's province.

The fourth category - arbitrary grabbing of land with the aim of artificial broadening of city limits without permission from municipalities. For

${ }^{6}$ Cheremisin A. (2014). The municipal legislation of the southern Ukraine at the 1870-1917. Applied sciences and technologies in the United States and Europe. New York. USA. P. 26-31. [in English]. 
example, in Olexandrivsk it caused a lot of displeasure from the part of selfgovernment bodies and the both sides of the conflict had to spend a lot of time in court authorities.

The fifth category - social misuses, as a result of which the poor strata of population had nothing at all or were content with disadvantageous land property, whereas the richer had concentrated in their hands land allotments of about 200-300 des., what is more the municipal budget did not collect a kopek of rent.

In this aspect the south of Ukraine differed substantially from other regions of the empire and had the regional-individual specifics, as it owned a tremendous lot of land property (from 2-4 thousand to 47 thousand des.), whereas in other regions municipal land property was in the limits of 2-4 thousand des. Conflicts around land property in other town were not known simply.

Thus, towns in the south of Ukraine were the biggest landowners in the empire and earned the biggest profits from usage of land fund. That's why it is not surprising that a great lot of conflicts were fixed on municipal lands. In other regions a fund of land property, profits and usage of it were too different from those in southern Ukraine. Only towns of Siberia were capable of concurrence in an amount of land resources, but the level of profitability in the south of Ukraine was higher. The attempts to modernize the exploiting of municipal lands took place only in the south of Ukraine. It was either of an unfinished character or did not influence substantially productivity of crops ${ }^{11}$. Still it commenced and self-government bodies realized that it was possible to use actual resources more rationally. In the studied period towns in the south of Ukraine were large landowners, but they did not develop their own agriculture, so municipalities had to lease lands with the aim of collecting a fixed income by means of taxation and charges giving to each leaseholder a freedom of establishing a system of economy. Thus, the whole land which was allotted to towns was municipal property, whereas the public enjoyed the right of using land through rent which they might lose if they would not follow the terms. As the negative features of this process we can mention the following: there was no motivation to invest substantial capitals in development of land allotments; there were no necessary material resources, too, as it was impossible to receive credits without pawning; towns received minimal revenues to budgets; it was necessary to support costly administration and municipality ${ }^{7}$.

${ }^{7}$ Shchepkin M. (1882). Opyty izucheniya obshchestvennogo hozyajstva i upravleniya gorodov. [Experimentsin the study of public economy and urban management]. M. : Tip. M. SHCHepkina, 1882. CH. 1. 256 s. [in Russian]. 


\section{Modernization of industrial complexes by self-government bodies}

After the municipal reforms of the second half of the XX c. there commenced an active industrial development of southern Ukrainian region. Municipal self-government made attempts of changing the very structure of industry and, as there was no any united body to control industrial enterprises, municipalities tried to take over functions of management and control. Magistrates' heads in 1870s wrote letters to the Minister of Home Affairs about necessary measures for improving the situation and suggested to apply privileges for industrial enterprises. Thus, it appeared that municipalities were active in the process of developing industry only after the Reform from 1870. It was noticed that the reason of the unsatisfactory condition of industry was connected with crop-failures which, according to statistical data of committees, took place constantly. However, the direct connection between the phenomena was not made ${ }^{8}$.

Towns of southern Ukraine received a powerful impetus to industrial development not due to the industrial revolution in proper, but due to the forming of a "radical mental-economic change" which was connected mainly with the population's development of enterprising and commerciality as well as necessary technical knowledge and sufficient amount of finances and credits.

In the south of Ukraine mineral raw materials were known already before the reform, but they were obtained only in small quantities. After the abolition of serfdom there appeared a burst of urbanity and plenty of population in towns increased; in direct proportionality to it there also increased a demand for municipal land which was not sufficient for everyone, so the population with the purpose of material security looked for jobs in the industrial sector.

The building of railroads influenced a development of factory industry that connected towns, which existed before it autonomously, on a basis of common interests. Apart from this, the conditions for a sale of production grew better not only in a neighbor province but also in a distant one. The industrial development of the province, according to the author, may be connected with hopes of urban population for better financial-material future, which also influenced industrialization, the development of trade qualities and at the same time there was an increase in knowledge which the population gained itself. Townspeople had no limitations already in the development of industry for

${ }^{8}$ Cheremisin O. V. (2011). Uchast administratyvnoho upravlinnia v rozvytku promyslovosti $\mathrm{m}$. Khersona kinets XVIII - persha polovyna XIX stolit. [Participation of administrative management in the development of industry in Kherson end of XVIII - the first half of the XIX century]. Istorychnyi arkhiv. Naukovi studii: Zbirnyk naukovykh prats. Mykolaiv : Vyd-vo ChDU im. Petra Mohyly. Vyp. 6. S 63-67. [in Ukrainian]. 
solving exceptionally local problems and needs, but they began to pay attention to market demands in provinces ${ }^{9}$.

In spite of tremendous achievements in industry already in the end of the XIX c. towns in the south of Ukraine remained agro-industrial to a greater extent, as the agriculture sector was still a basis of municipal economy and the structure of industry was built on its foundation ${ }^{10}$.

Coal-mining industry influenced the formation and development of the city of Lugansk. In 1795 a factory became a construction site for a whole town that received its self-government in 1870 . This branch of industry promoted development of Slavyanoserbsk which(a former out-of-the-way place) became a powerful industrial center. The significant efforts made by selfgovernment of Katherinoslav province were aimed at building of railroads without which raw minerals production in large amounts would be impossible. Municipalities participated in building Donetsk, Katherinoslav and KurskKharkov-Azov railroad systems which consisted of 26 stations and were adjusted for working with various mineral cargoes. The State's support for development of regional industry was realized through facilitating the building of railroads, through high taxes on imported cast-iron, coals and other minerals which were imported from abroad through sea ports; not to mention that metallurgic factories were also built with the support of the State ${ }^{11}$.

The role of municipal self-government bodies in the development of industry was not substantial, to be correct, it was minimal, as, on the one hand, they were not engaged in industrial problems without outer support, whereas they tried only to lease enterprises, on the other hand, the division of enterprises subordinating them to branch ministries did not provide possibilities for municipalities to freely orientate themselves in industrial sector, and the third, the crucial role in the development of industry in the region was played by powerful foreign financial corporations such as: "New Russian Society of coal-mining, iron and railroad production" with the headquarters in GB; French company "Mining and Industrial Society in the south of Russia" and in economical environment of which there was no concurrence from the part of self-government bodies.

${ }^{9}$ Pavlovich V. (1862). Materialy dlya geografii i statistiki Rossii. [Materials for geography and statistics of Russia. Ekaterinoslav province]. Ekaterinoslavskaya guberniya. Spb. : Tip. depertamenta general'nogo shtaba. 402 s. [in Russian].

${ }^{10}$ Golobov Ya.G. (1912). Pamyatnaya knizhka i adres-kalendar' dlya Ekaterinoslavskoj gubernii na 1912 g. [Memorial book and calendar address for the Ekaterinoslav province in 1912]. Ekaterinoslav: Tip. ekaterinoslavskogo gubernskogo pravleniya. $428 \mathrm{~s}$. [in Russian].

11 Totomianc V.F. (1910). Samoupravlenie i gorodskoe hozyajstvo. [Self-government and urban economy]. SPb. : V.V. Bitner. 79 s. [in Russian]. 
Thus, self-government was far from organizing industrial enterprises. Its role was limited by giving permissions for building factories and plants, leasing municipal land for building and for conducting current statistics on quantity and quality and amount of production in industrial enterprises having no direct relationships to them.

The main distinctive feature of transition from the XIX to XX c. was that towns became more interconnected to each other. For example, the development of Lugansk's industry influenced negatively the condition of Slavyanoserbsk from which a moving of urban population increased and there commenced a curtailment of industrial enterprises and a rate of life did not look like urban; instead it was similar to that of countryside. Most towns of Katherinoslav province were still agrarian or became of that type in the XX c. with traditional thinking characteristic for this type of municipal self-government workers.

The situation did not change absolutely until 1917. Only a number of factories and plants increased as well as a volume of production, but the role of municipal self-government bodies in this process remained unchanged. In the stormy years of the Revolution towns of Katherinoslav province were still agricultural. During this process municipalities engaged themselves in creating myths exaggerating artificially their role in the process, as if it was they whose permissions were crucial for building industrial enterprises as well as leasing land. In reality permissions were given only for the building or establishment of $1 \%$ industrial enterprises and not very large ones. In their reports municipalities were constantly proud of level of industrial development as well as the increase in production and of other issues, but they had no connection to organization and sale of production; in reality they were simply statistical committees for the industries.

Thus, due to the participation of municipal self-government bodies a net of railroads was built, which sufficiently accelerated the industrial development and increased a rate of production, it also made it possible for a lot of rustic population to move to towns and find a job in industrial enterprises and it were railroads due to which the province acquired a status of industrial region every year, although in reality not only municipalities but also the State together with big financial companies took part in the building of railroads; that is why a role of self-government was a little overestimated in the process. It is worth mentioning that the importance of municipalities was emphasized by self-governmental institutions themselves.

In the mentality of urban population and self-government bodies there formed clear understanding that a place of living might be a matter of proud e.g. factory production, a center of coal-mining industry's life of the state and that due to all of it the industrial "feeding" of a region and the state was realized, but the importance of it was to a greater extent overprized, as, in fact, 
the region before 1917 was more agrarian than industrial; the percentage of employed population was also bigger in the agrarian sector of economy than in the industrial one.

Thus, according to the statistical data from 1874 in regard to a level of the development in mining industry the south of Ukraine took only 6-th place among 11 regions where anthracite, coal and iron were mainly produced. In this we can trace a regional-individual peculiarity of the region which specialized in coal and metallurgic production. Gold-mining industry was successfully developed in Siberian provinces mainly. Platinum industry was actively developed in Perm and Orenburg provinces. Silver was mined in the Caucasus, Zabaykalje and Semipalatinsk regions. Zinc industry was developed in the Tsarstvo Polskoe and Petrovska province. Tin was mined in Finland and in Zabaykajle. Cupper was mined in Permskaja, Orenburgskaja, Kazanskaja, Tifliskaja, Tomskaja, Tobolskaja and other provinces. The leaders in metallurgic industry were Permskaja, Ufimskaja and Penzenskaja provinces. Metallurgic production in Katherinoslav province took the 19 place among 20 provinces of the empire, leaving only Mogilevska behind and giving up its place to Volynska province ${ }^{12}$.

Thus, metallurgic production in 1870 was greatly overestimated in southern Ukrainian towns. The prospects for the Donbas were described as rather optimistic, regarding it as one of the perspective and new industrial regions of the empire, though on conditions of private initiatives' development. Thus, due to industrial development and private capital in the second half of the XIX c. there appeared "new" industrial-modernization towns - Donetsk and Lugansk. One can consider a regional-individual feature of the southern Ukrainian region as a common fact, as only in the south the Government let private people invest money in metallurgic and coal production.

The Donbas coal basin was regarded as one of the largest in the Russian empire, though it gave its place to Tulskaja, Razanskaja, Novgorodskaja and Kaluzhskaja provinces in its development. Judging by the output of coal and anthracite the industrial enterprises of Katherinoslav province obtained already 6 million coals and 14 million puds anthracites in 1871. Raw oil production took place mainly in Russia's provinces. In the Crimea deposits of oil were found, though they took the $8^{\text {th }}$ place among $9^{13}$.

According to the statistical data from 1893 on the territory of Katherinoslav province there commenced the production of manganese ore near a town of Nikopol in 1886. However, the output gave its place to those in the Caucasus and Ural. In regard to the output of coal the Donetsk coal joined the leaders

${ }^{12}$ Levron V. (1874). Statisticheskoe obozrenie Rossijskoj imperii. [Statisticalreview of the Russian Empire]. SPb. : Tip. «Obshchestvennaya polza». S. 98-156. [in Russian].

${ }^{13}$ Ibid. 
giving its place only to Ural provinces. Thus, in the Ural region 56 millions coal were mined, whereas in Katherinoslav 22 million puds only.

Judging by the export of minerals abroad the ports of Baltic Sea were the leaders, whereas the ports of the Sea of Azov and the Black sea ports took the last positions. Thus, according to the statistical data from 1890 from the ports of Baltic Sea 74 millions puds were exported, whereas from the Black Sea and the ports of the Sea of Azov 10 million puds were exported in total, as for the ports of Baltic Seas a more favorable tax system was applied. In the south of Ukraine the system was the least favorable.

Notwithstanding the substantial progress in modernizational and industrial development in the south of Ukraine, which became one of the main industrial regions in the empire within less than a century, thelevel of development remained slow and it fell behind countries of West Europe and USA. To the most extent it was due to obsolete forms and methods of management, as the region was still agrarian. Industrial-modernizational development in the south of Ukraine continued after the liquidation of serfdom, the breaking of traditional patriarchal relationships which, by the way, were very deep-seated in Moscow province, whereas the south was regarded as a more modernized region. With the beginning of building the Donbas coal basin there appeared new towns in the South - Donetsk and Lugansk.

The role of municipal self-government bodies was not vivid even in mobility of industrial development, it did not show any changes during a rather long period of time and in regard to its adaptation to capitalistic market conditions it remained under traditional mental schemes even being never interested in social conditions of workers in factories and their medical security. However, the municipalities' role was more significant in spreading an idea of industrialism as a component for leadership among other regions and towns and from this starting point there prospered a town's patriotism. Thus, within only several decades after the Reform period due to a mental construction of municipalities towns in Katherinoslav province turned from out-of-way rustic places into powerful industrial enterprises, remaining, in fact, far from this image.

During the studied period in towns of Tavrijskaja province the following branches of factory industry were developed: processing of stock-breeding products -71 (soap, fish, leather, morocco and other production), processing of plant-growing products - 33 (vinegar, tobacco, floury, wood-sawing, starch, oil-mill, brewing, match and others), processing of mining products 24 (brick stone, iron, mining), mixed production - 15 (chemical, blacksmith's and others) $)^{14}$.

${ }^{14}$ Feferbojm I.A. (1896). Yuzhnaya Rossiya. Putevoditel po gorodam. [Southern Russia. Cityguide]. Nikolaev : Russkaya tipo-litografiya. 176 s. [in Russian]. 
The tendency towards development manifested itself in the fact that during the post reform period factories and plants appeared in those towns where there weren't any before the Reform period. For example, in Oleshki there were no enterprises of factory industry before 1870, but already in 1892 there appeared 6 chemical plants in the town. Thus, radical industrial change manifested itself even in absolutely agrarian towns in which the absolute majority of population was busy with agriculture ${ }^{15}$.

Comparatively only towns in Katherinoslav province obtained powerful industrial development. Khersonska and Tavrijska provinces remained agrarian territoriesto the most extent, though they felt an effect of factory development and there appeared industrial enterprises in those towns which in regard to their lifestyle were nearly agrarian. Thus, we can speak about negative tendencies in development of industrial potential of towns as well as factors which influenced this very process; we can speak about critical attitude from the side of public institutions concerning participation in this process, but we can state that in comparison with other regions of the empire in the south of Ukraine the situation did not seem so difficult or problematic.

Thus, during the modernizational period in the second half of the XIX - the beginning of the XX c. the role of municipal self-government bodies was represented in the following: the participation in building a means of communication (railways) and ports' modernization; the leasing of municipal property and receiving revenues to budgets which were allotted to towns' development.

In general, towns in the south of Ukraine felt themselves as self-sufficient social-economical organisms, but at the same time they were limited in their self-government, which caused displeasure from the part of those who were not advocates of the autocracy. In the end of the XIX - at the beginning of the $\mathrm{XX} \mathrm{c.} \mathrm{there} \mathrm{appeared} \mathrm{works} \mathrm{by} \mathrm{liberally} \mathrm{thinking} \mathrm{lawyers,} \mathrm{historians} \mathrm{and}$ political figures in which a lot of attention was paid to disadvantages of an existing system of power, ways of improvement, organization and functioning of municipal self-governmental institutions; a variety of ways for their development were also suggested.

${ }^{15}$ Hanackij K.V. (1867). Pamyatnaya knizhka Tavricheskoj gubernii na $1867 \mathrm{~g}$. [Memorial book of the Tauride province for 1867]. Simfereopol: Tip. tavricheskogo gubernskogo pravleniya. 657 s. [in Russian].; Gorlovskij D. (1897). Otchet hersonskoj gorodskoj upravy za 1896 g. [Kherson City Council Reportfor 1896] Herson, Tip. O.D. Hodushinoj. S. 23-89. [in Russion].; Golobov Ya.G. (1912). Pamyatnaya knizhka i adres-kalendar dlya Ekaterinoslavskoj gubernii na 1912 g. [Memorial book and calendar address for the Ekaterinoslav province in 1912]. Ekaterinoslav: Tip. ekaterinoslavskogo gubernskogo pravleniya. 428 s. [in Russian].; Verner K.A. (1888). Pamyatnaya knizhka Tavricheskoj gubernii na $1889 \mathrm{~g}$. [Memorial book of the Tauride province for 1889]. Simfereopol : Tip. «Krym». 697 s. [in Russian]. 
The substantial part of publicist and scientific-popular works by liberally and socialistically thinking authors about municipal self-government institutions was aimed at a practical task: to involve masses in political life, to appeal for struggle against the autocracy, that is why such publications were biased and tendentious. In the most cases a social composition of deputies was mainly criticized for supposedly being guilty of having made municipalities incapable of working effectively for the benefit of all townspeople or for being incapable of managing rationally or for strict control from the part of the Government, for centralization as well.

The critics knew prerevolutionary foundations of conducting municipal economy. Information which was given in the publicists' works about the success of western towns was to be "the most eloquent reproach of our criminal indifference towards such matters." As a result, the authors suggested demands for "new life" in regard to self-government bodies: substantial broadening of electoral rights, weakening of the Government's control, cancelling of obligatory expenditures, turning of municipalities' functioning to the development of economic potential, education-culture spheres, medicosanitary activity, towns development and communal sphere of municipal economy.

\section{CONCLUSIONS}

Thus, the self-government in the south of Ukraine manifested significant modernization mobility in conducting economical policy. Each municipality was completely individual in the process of solving problems of industrial development, modernization of land policy, modernization of ports' structures, etc. From the point of view of competitiveness the self-government bodies in the south of Ukraine showed a high level of mobility in this aspect.

In general, although municipal-self-government bodies acted on the basis of general legislation, they solved questions of leasing land in an individual way either while municipalizing industrial enterprises or when it was necessary to build means of communication or to modernize ports or develop trade routes. Each municipality looked for sources of financing the abovementioned projects, as a municipal budget could not cover expenditures neither on building railways nor ports' modernization, that's way public institutions received credits on security in an individual way. It goes without saying that modernizational tendencies were not spread in all towns of the southern Ukraine. The majority of towns in the south realized that their future life and prospects were completely dependent on new modernizing events: on railroads which would provide economical and urbanity drive; on engineering infrastructure which would give more comfortable social-communal conditions of life. The towns, which were able to provide building railroads, acquired fast industrial-commercial development. The population increased 
and town's environment widened. That's why only those towns in the south of Ukraine became urbanized and modernized which used necessary potential the capitalism's time required. They built railways to modernize ports connecting by means of new trade routes administrative centers and provincial towns to ports, to regional centers or big cities in the south of Ukraine thus to receive new conditions of life which substantially would surpass in indicators in other regions of the country. In comparison with other regions of Ukraine, Russia, Belarus, Baltic regions the self-government bodies in the south of Ukraine showed positive examples of new modernizing possibilities.

\section{SUMMARY}

The article deals with problems of modernizing economical potential of self-governmental (decentralized) bodies during the second half of the XIX at the beginning of the XX c. The major emphasis is put on the modernization of land policy and industrial complexes. The ideas, which were used during the activity of the prerevolutionary self-governmental bodies, are still of practical interest. The actual realization of municipal self-governmental experience may give modern regions a substantial economical and urbanization on impulse and can also influence the development of engineering infrastructure, which might provide more comfortable socialcommunal conditions of life. It is mentioned in the conclusions that according to the results of modernizational changes during the studied period selfgovernment bodies made significant progress in development of socialeconomical potential. In comparison with other regions of Ukraine, Russia, Belarus, the Baltic regions the self-government bodies in the south of Ukraine showed positive examples of new modernizational possibilities. As a result of the conducted research, it may be concluded that self-government in the south of Ukraine manifested significant mobility in realizing regional economical policy.

\section{REFERENCES}

1. Gorlovskij D. (1897). Otchet hersonskoj gorodskoj upravy za $1896 \mathrm{~g}$. [Kherson City Council Reportfor 1896] Herson, Tip. O. D. Hodushinoj. S. 23-89. [in Russian].

2. Konstantinova V. M. (2010). Urbanizaciya: pivdennoukraïnskij vimir (1861-1904 rokah). [Urbanization: South-Ukraini and imension (1861-1904)]. Zaporizhzhya : AA Tandem. S. 216-217. [in Ukrainian].

3. Pavlovich V. (1862). Materialy dlya geografii $i$ statistiki Rossii. [Materials for geography and statistics of Russia. Ekaterinoslav province]. Ekaterinoslavskaya guberniya. Spb. : Tip. depertamenta generalnogo shtaba. 402 s. [in Russian]. 
4. Levron V. (1874). Statisticheskoe obozrenie Rossijskoj imperii. [Statisticalreview of the Russian Empire]. SPb. : Tip. "Obshchestvennaya pol'za". S. 98-156. [in Russian].

5. Feferbojm I. A. (1896). Yuzhnaya Rossiya. Putevoditel' po gorodam. [Southern Russia. Cityguide]. Nikolaev : Russkaya tipo-litografiya. $176 \mathrm{~s}$. [in Russian].

6. Shchepkin M. (1882). Opyty izucheniya obshchestvennogo hozyajstva $i$ upravleniya gorodov. [Experimentsin the study of public economy and urban management]. M. : Tip. M. SHCHepkina, 1882. CH. 1.256 s. [in Russian].

7. Cheremisin A. (2014). The municipal legislation of the southern Ukraine at the 1870 - 1917. Applied sciences and technologies in the United States and Europe. New York. USA. P. 26-31. [in English].

8. Cheremisin A. (2014). Municipal budgets of the southern Ukraine at 1785-1870. British journal of science, education and culture. 1 (5). P. 17-24. [in English].

9. Cheremisin O. V. Miski biudzhety Pivdnia Ukrainy v 1870-1917 rr. Naukovi zapysky Ternopilskoho natsionalnoho universytetu im. V. Hnatiuka. Seriia: Istoriia. Ternopil : Vyd-vo TNPU im. V. Hnatiuka, 2015. Vyp. 1. Ch. 2. S. 17-23. [in Ukrainian].

10. Cheremisin O. V. (2011). Uchast administratyvnoho upravlinnia $\mathrm{V}$ rozvytku promyslovosti $\mathrm{m}$. Khersona kinets XVIII - persha polovyna $I$

XIX stolit. [Participation of administrative management in the development of industry in Kherson end of XVIII - the first half of the XIX century]. Istorychnyi arkhiv. Naukovi studii: Zbirnyk naukovykh prats. Mykolaiv : Vyd-vo ChDU im. Petra Mohyly. Vyp. 6. S 63-67. [in Ukrainian].

11. Fesenko I. O. (1900). Vazhnyj vopros gorodskogo hozyajstva. Uchastie kvartirohozyaev $\mathrm{v}$ gorodskom upravlenii. [Animportantissue of urban economy. Participation of tenantsin city administration]. SPb. : Tipografiya MVD. 107 s. [in Russian].

12. Tsybulenko L. O. (2001). Diialnist orhaniv samovriaduvannia Odesy, Mykolaieva, Khersona shchodo formuvannia i rozvytku munitsypalnoi zemelnoi i vyrobnychoi vlasnosti v XIX - na pochatku XX stolit. [Activities of self-government bodies of Odessa, Nikolaev, Kherson on the formation and development of municipal land and industrial property in the XIX - early XX centuries]. Dnipropetrovsk. S. 32-40. [in Ukrainian].

13. Turchenko F. H., Turchenko H. F. (2003). Pivdenna Ukraina: modernizatsiia, svitova viina, revoliutsiia (kinets XIX st. - 1921 r.): Istorychni narysy. [South Ukraine: Modernization, World War, Revolution (end of the XIX century - 1921): Historical essays.]. K.: Heneza. 304 s. [in Ukrainian].

14. Totomianc V. F. (1910). Samoupravlenie i gorodskoe hozyajstvo. [Self-government and urban economy]. SPb. : V. V. Bitner. 79 s. [in Russian]. 
15. Golobov YA. G. (1912). Pamyatnaya knizhka i adres-kalendar' dlya Ekaterinoslavskoj gubernii na $1912 \mathrm{~g}$. [Memorial book and calendar address for the Ekaterinoslav province in 1912]. Ekaterinoslav : Tip. ekaterinoslavskogo gubernskogo pravleniya. 428 s. [in Russian].

16. Hanackij K. V. (1867). Pamyatnaya knizhka Tavricheskoj gubernii na $1867 \mathrm{~g}$. [Memorial book of the Tauride province for 1867]. Simfereopol' : Tip. tavricheskogo gubernskogo pravleniya. 657 s. [in Russian].

17. Verner K. A. (1888). Pamyatnaya knizhka Tavricheskoj gubernii na 1889 g. [Memorial book of the Tauride province for 1889]. Simfereopol : Tip. "Krym". 697 s. [in Russian].

\section{Information about the author: Cheremisin Oleksandr Viktorovych, Prof. drhab.,} Professor at the Department of Professional Education Kherson State Agrarian and Economic University 23, Stritenska str., Kherson, Ukraine, 73006 orcid.org/0000-0003-0173-0489 